21. Bearth, P. Atlas Géol. Suise Saas and Monte Moro (Schweiz. Geol. Kommission, Basel, 1957)

22. Klein, J. A. Leid. geol. Meded. 51, 233-312 (1978).

23. Muller, R. Eclog. geol. Helv. 76, 391-416 (1983)

24. Milnes, A. G., Greller, M. \& Mulfer, R. J. struct. Geol. 3, 411-420 (1981)

25. Lacassin, R. thesis, Univ. Montpellier (1984).

26. Lacassin, R. Tectonics (submitted).

27. Lasin, R Cr. hebd Séanc. Acad Sci, Paris 296, 777-782 (1983).

28. Lacassin, R. C.r. hebd. Séanc. Acad. Sci., Paris 297, 613-618 (1983).

29. Ramsay, J. G. \& Graham, R. Can. J. Earth Sci. 7, 786-812 (1970).

30. Escher, A. \& Watterson, J. Tectonophysics 22, 223-231 (1974)

31. Malavieille, J. Bull. Soc géol. Fr. 26, 129-138 (1984).

32. Mattauer, M. C.r. hebd. Séanc. Acad. Sci., Paris 293, 929-932 (1981).

33. Mattauer, M. Earth planet. Sci. Lett. 28, 144-154 (1975).

34. Sanderson, D. Tectonophysics 16, 55-70 (1973).

35. Berthé, D. \& Brun, J. P. J struct Geol. 2, 127-133 (1980).

36. Hugon, H. thesis, Univ. Rennes (1982).

37. White, S., Burrows, S., Carreras, J., Shaw, N. \& Humphreys, F. J. struct. Geol. 2, 175-187 (1980)

38. Hobbs, B., Means, W. \& Williams, P. An Outline of Structural Geology (Wiley, New York, 1976).

39. Nicolas, A. \& Boudier, F. Tectonophysics 25, 233-260 (1975).

40. Malavieille, J., Lacassin, R. \& Mattauer, M. Butl. Soc, géol. Fr. 26, 895-906 (1984).

41. Mattauer, M., Faure, M. \& Malavieille, J. J. struct. Geol. 3, 401-409 (1981).

42. Van Den Driessche, J. Tectonophysics (in the press).

43. Laurent, P. \& Etchecopar, A. Bull. Soc. géol. Fr. 18, 1387-1393 (1976).

44. Malavieille, J. \& Etchecopar, A. Tectonophysics 78, 65-71 (1981).

45. Hubert, M., Ramsay, J. G. \& Simpson, C. Eclog. geol. Helv. 73, 593-607 (1980)

46. Simpson, C. Eclog. geol. Helv. 75, 495-516 (1982).

47. Cobbold P. J. struct. Geol. 1, 338 (1979).

48. Steck A Bull geol Lausanne $252(1980)$

49. Steck, A. Eclog. genl. Helv. 77, 55-100 (1984).

\section{An early Cambrian rift to post-rift transition in the Cordillera of western North America}

\author{
Gerard C. Bond, Nicholas Christie-Blick, \\ Michelle A. Kominz \& William J. Devlin
}

Lamont-Doherty Geological Observatory of Columbia University, Palisades, New York 10964, USA

The upper Proterozoic and lower Palaeozoic wedge of miogeoclinal strata in the North American Cordillera is widely regarded as evidence for a proto-Pacific passive $\operatorname{margin}^{1-3}$. The rifting history of this margin appears to have been protracted, possibly spanning >200 Myr in a tectonic setting that is not well understood $^{3}$. Quantitative subsidence analyses of lower Palaeozoic strata between British Columbia and Utah, however, provide indirect evidence that the transition from rifting to post-rift cooling occurred within a relatively short interval of time, although probably not synchronously, between 600 and $555 \mathrm{Myr}$ (refs 4-6). This age is significantly younger than that implied in previous studies $^{1,2}$. We describe here new field data, which, together with published geological data, provide direct evidence of a latest Proterozoic or early Cambrian age for the rift to post-rift transition. The data support recent arguments for widespread initiation of passive margins around the edge of the North American craton close to the Cambrian-Precambrian boundary ${ }^{7}$.

Indirect evidence for the ages of the rift to post-rift transition as well as for the final rifting phase were inferred from tectonic subsidence curves for early Palaeozoic strata in the Cordilleran miogeocline $\mathrm{e}^{4-6}$ (Figs 1, 2). The strata (ranging from early Cambrian to late Ordovician in age) are laterally continuous, stable-shelf deposits and are regarded as part of an extensive post-rift continental terrace ${ }^{1-3}$. The tectonic subsidence curves have the same form as the age-depth curve for ocean floor (Fig. 2 ). This indicates that, as in modern passive margins, the post-rift tectonic subsidence was controlled mainly by contraction of the lithosphere resulting from the decay of thermal anomalies generated during rifting ${ }^{4-6}$. We emphasize, however, that the curves do not distinguish between margins adjacent to an open ocean or a back arc basin. The steep slopes of the curves, which are a function of the rates of heat loss, place the maximum age for the beginning of post-rift cooling at $\sim 600 \mathrm{Myr}$ (refs $4-6$ ). This is because older ages for initiation of post-rift cooling, at $650 \mathrm{Myr}$, for example, would require anomalously high rates of heat loss from the Cambrian ocean floor, reaching at least $160 \%$

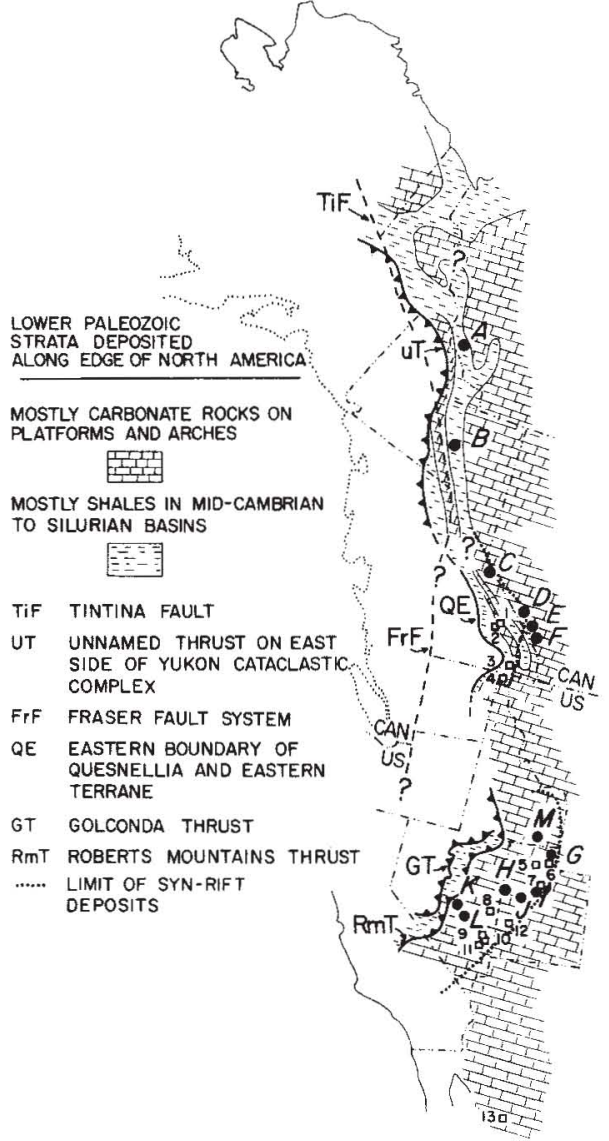

Fig. 1 Distribution of the lower Palaeozoic miogeoclinal facies in western North America (modified from ref. 5). UT, QE, GT and RMT are major structural boundaries of various terranes accreted to western North Amerca in post-early Palaeozoic time ${ }^{3}$. These boundaries mark the westernmost preserved edge of the lower Palaeozoic North American continent. Ti-FrF is a major rightlateral transcurrent fault system ${ }^{3}$. The dotted outline of western North America gives the position of this region after restoration of the right-lateral transcurrent movement on the Tintina-Fraser fault system ${ }^{5}$. Heavy dotted lines indicate the approximate eastern limits of the latest Proterozoic or earliest Cambrian postWindermere rift deposits in the southern Canadian Rockies and in Utah-Nevada. Locations of sections in which tectonic subsidence has been calculated ${ }^{4,5} . \square$, Locations where mafic extrusive rocks occur in post-Windermere rift deposits that record the final (latest Proterozoic or early Cambrian) rifting in the margin. Sources: $1,2,3$, Hamill Group ${ }^{15,16,35} ; 4$, Three Sisters Formation (although the volcanics may be in the Windermere Supergroup, F. Miller, personal communication); 5, Mutual Formation (Crittenden, unpublished mapping); 6, Browns Hole Formation ${ }^{23}$; 7 , Tintic Quartzite ${ }^{30} ; 8,12$, Prospect Mt Quartzite ${ }^{26,29} ; 9-11$ Stirling Quartzite $^{26} ; 13$, Sonora ${ }^{33,34}$.

of that of the modern ocean floor ${ }^{5}$. The high rates of post-rift cooling further indicate that relatively little heat was lost during rifting, and in terms of finite rifting models ${ }^{9}$, the duration of the final rifting phase probably did not exceed $10-20 \mathrm{Myr}$. The age of final rifting, therefore, could not be much older than our inferred maximum estimate for the rift to post-rift transition.

The subsidence data do not preclude earlier extensional and heating events, which are indicated by geological evidence and have profoundly influenced the structural evolution of the margin, probably since the Middle Proterozoic ${ }^{2,3,10}$. However, igneous rocks thought to be associated with late Proterozoic rifting in the margin have radiometric ages of $\sim 900-750 \mathrm{Myr}$ (refs $8,10,11$ ), and clearly are too old for the final rifting of the margin. Our mapping in the southern Canadian Rockies and in Utah, together with a synthesis of published data, have led to the identification of a widespread younger rifting event 
Fig. 2 Tectonic subsidence $(-)$ for sections located in Fig. 1 compared with thermal subsidence curves from the McKenzie stretching model ${ }^{36}$ (solid curves). Large dots are stratigraphical boundaries to which numerical ages have been assigned. Small dots are formation boundaries positioned by assuming constant sedimentation rates between dated boundaries. Vertical bars give the range between maximum and minimum values of tectonic subsidence ${ }^{4}$. Horizontal bars give an assumed \pm 5 -Myr error for stratigraphical correlations with numerical ages. $\beta$, Crustal stretching factors from the McKenzie stretching model; $\beta$ values corresponding to the subsidence curves are not necessarily the stretching factors for the passive margin. Letters with subscripts designate different sections lying along east-west lines at locations that are too close to indicate separately in Fig. 1. The higher subscript numbers designate the more westerly sections. Most of the sections with subscripts are $>15 \mathrm{~km}$ apart on a non-restored base. Numerical ages assigned to the stratigraphical boundaries ${ }^{20}$ are shown in the upper right-hand corner. Stratigraphical boundaries are from ref. 37 .

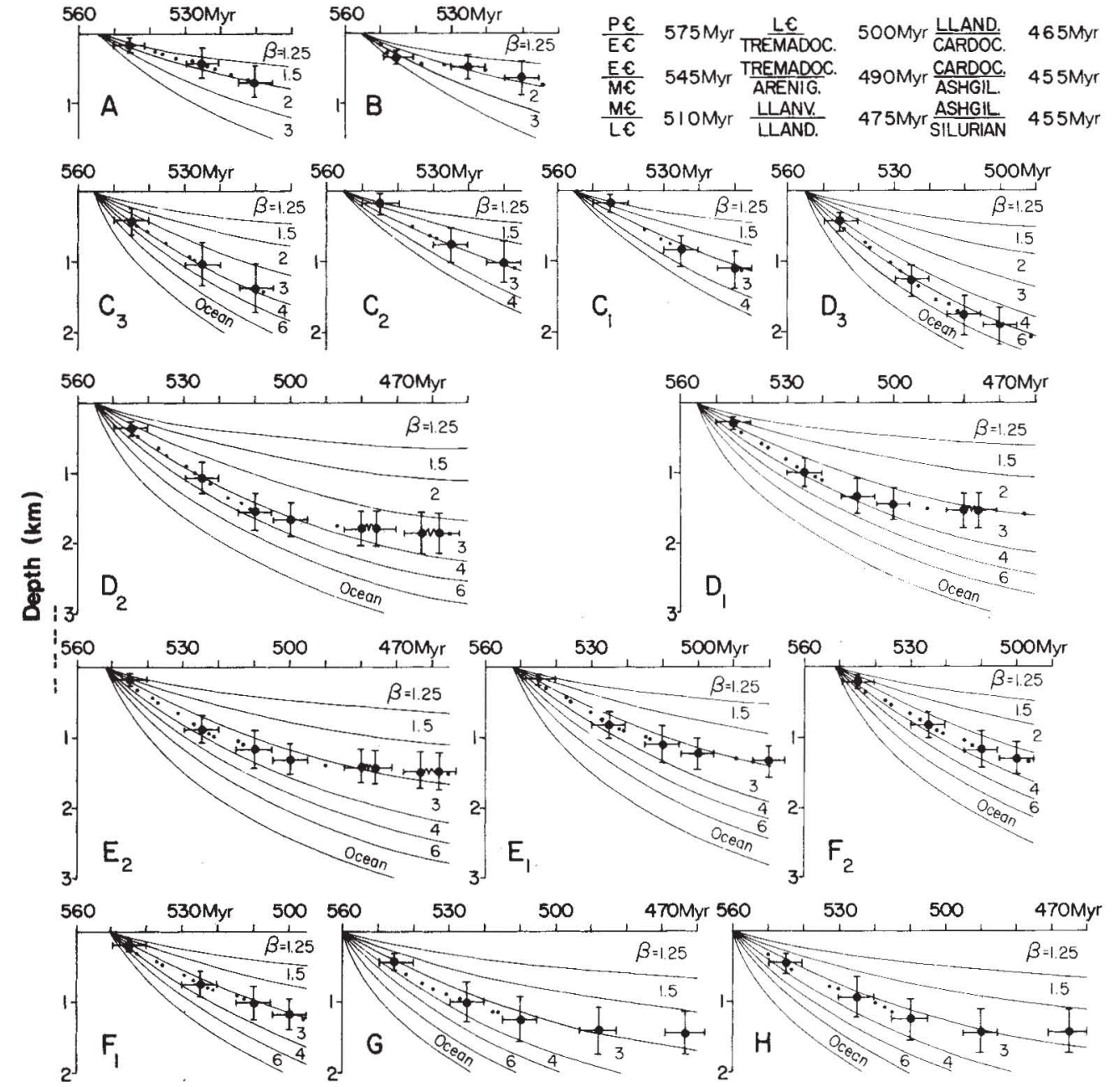

whose age appears to be compatible with the high rates of post-rift cooling in the margin.

In the southern Canadian Rockies, limited evidence for younger rifting has been reported from the Hamill Group west of Golden ${ }^{4,12}$ and from the McNaughton Formation near Jasper $^{13}$ (Fig. 3). Both deposits underlie strata with early Cambrian trilobites and overlie the Windermere Supergroup (Fig. 4a), a widespread stratigraphical unit that was deposited during rifting in late Proterozoic time (refs 2, 3, 10, 11). Both the Hamill Group and McNaughton Formation contain distinctive thick sequences of feldspathic sandstones and conglomerates $^{13-16}$ (Fig. 4a). In the Hamill Group west of Golden (Fig. 3), shallow-marine sediments pass abruptly into deeper marine deposits that contain resedimented sandstones, pillowed lavas and mafic volcaniclastic debris ${ }^{12,15,16}$. These facies changes are regarded as evidence of syn-depositional faulting accompanied by extrusion of mafic rocks ${ }^{12}$. Similarly, near Jasper, abrupt changes in thickness in the McNaughton Formation have been interpreted as evidence of syn-depositional faulting ${ }^{13}$. Strata of the Hamill Group and the McNaughton Formation pass gradationally upwards into the lower Cambrian mature quartz sandstones with Skolithos that are part of the early post-rift strata of the margin (Fig. 4a). Neither, however, is overlain by post-rift strata that are suitable for quantitative analysis, and their precise stratigraphical postion relative to a rift to post-rift transition cannot be inferred from subsidence data.

Recent field work in areas east and south of the exposures of the McNaughton Formation and Hamill Group (between $51^{\circ} 45^{\prime}$ and $52^{\circ} 30^{\prime}$, Fig. 1) has indicated that at least two of the sections analysed, SF and MtWi, and probably HL7b and GL as well (Fig. 3), are underlain conformably by a rift-like deposit that is at least $500 \mathrm{~m}$ thick. This deposit forms a distinctive basal unit of the Gog Group and is broadly correlative with the McNaughton Formation and at least the lower part of the Hamill Group $^{17}$ (Fig. 4a). The exact stratigraphical relation of this deposit to formally recognized strata in the region is not yet established, however, and we refer to it informally as a basal conglomeratic unit of the Gog Group.

A rift origin of the basal conglomeratic unit is suggested by a striking succession of cross-bedded, poorly sorted arkosic to subarkosic sandstones and conglomerates interbedded with thin layers of red shales and siltstones in the lower two-thirds of the unit (Fig. 4a). The sandstones and conglomerates contain $\sim 30-$ $80 \%$ quartz, $15-50 \%$ feldspar, more than half of which is a distinctive pink alkali feldspar as much as $2 \mathrm{~cm}$ across, and $5-20 \%$ rock fragments consisting mainly of quartzite, chert and granitic clasts. A total of 219 measured orientations of trough axes and large-amplitude $(50 \mathrm{~cm}$ to $2 \mathrm{~m}$ ) cross-beds, corrected for tilting, indicate mainly unimodal westerly current flow. The coarse grain size, arkosic composition, abundance of red shales together with westerly palaeocurrent directions suggest a fluvial or alluvial fan environment and a strongly uplifted source in crystalline basement to the east. An easterly provenance in crystalline basement has also been suggested for the McNaughton Formation based on palaeocurrent measurements and sandstone compositions ${ }^{13,18}$. The abrupt terminaton of the conglomeratic unit between Mt Chephren and Bow Pass (Figs $3,4 a$ ) could reflect deposition against a fault scarp or hinge zone flanking the easterly basement source. The conglomeratic unit of the Gog Group grades upward into mature quartz sandstones with Skolithos, which are correlative with the post-rift deposits in the upper part of the McNaughton Formation and in or above the upper part of the Hamill Group (Fig. $4 a$ ). These Skolithos-bearing strata form the base of the sections used in subsidence analyses. 


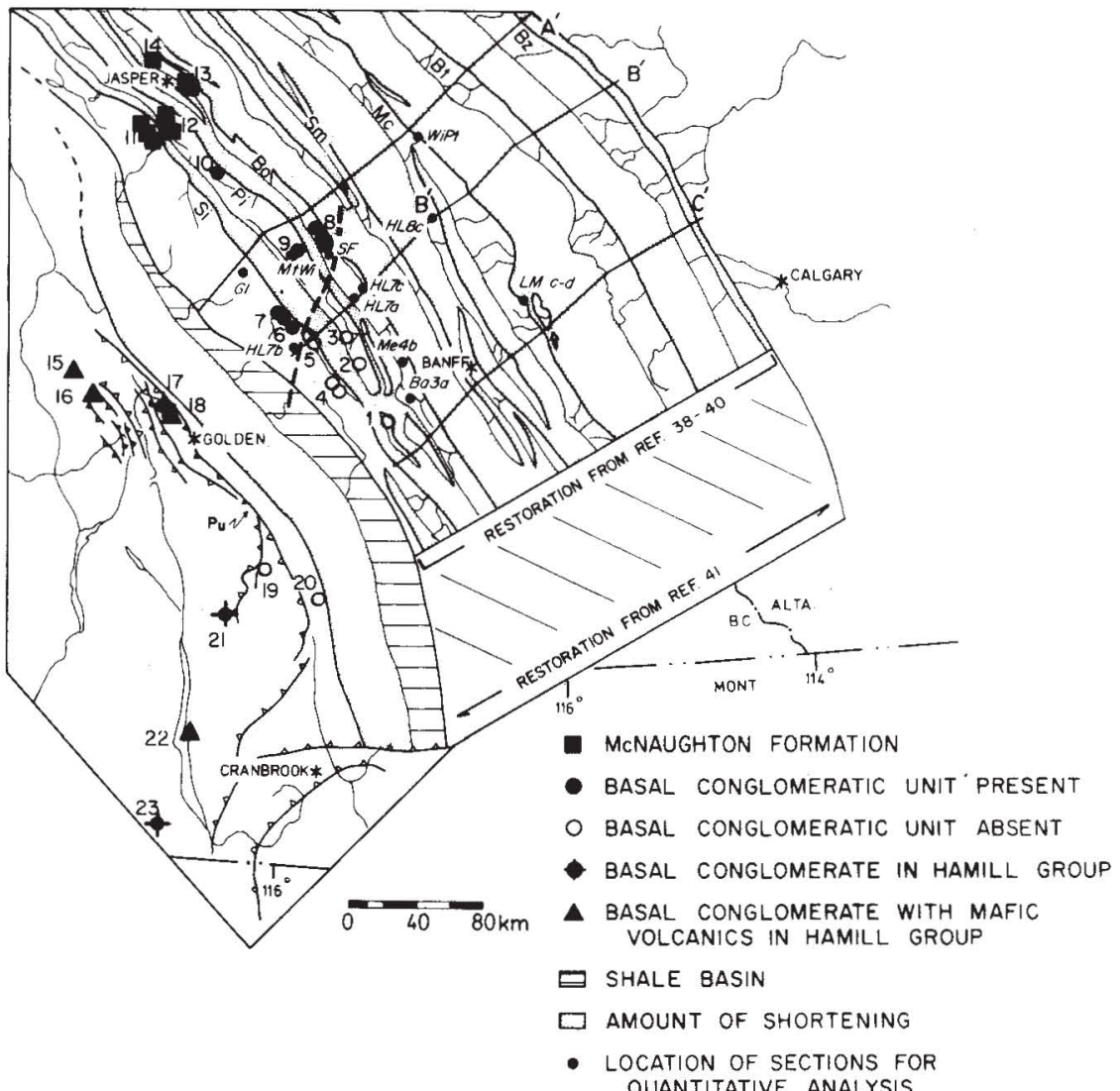

Fig. 3 Distribution, on a palinspastic restoration, of the uppermost Proterozoic to lowest Cambrian strata that are interpreted to record the final rifting and the transition to post-rift subsidence in the southern Canadian Rockies. Large filled circles, solid circles, solid circles with cross, solid squares, open circles and solid triangles mark localities examined in the field. Open circles west of Banff are the Gog Group and south of Golden are the Cranbrook Formation. Stippled area is the amount of shortening between thrust panels that are unpatterned. The shortening in the shale basin has not been determined from balanced sections and is assumed here to be equal to the amount of shortening in the carbonate bank (a factor of 2). The displacement on thrusts west of the shale basin has not been estimated. Italic letters correspond to analysed sections shown in Fig. 1. WiPt, SF, $M t W i, G L$ are at locality D, Fig. $1 ; H L 8 c, H L 7 c$, $H L 7 a, H L 7 b$ are at locality E, Fig. 1, and $L M C$ $D, M e 4 b$ and $B a 3 a$ are at locality F, Fig. 1. Lines $\mathrm{A}^{\prime}, \mathrm{B}^{\prime}$ and $\mathrm{C}^{\prime}$ are lines of palinspastic restoration which are control for restored positions of thust plates ${ }^{38-42}$. The dashed line is the approximate position of the southeastern edge of the basal conglomeratic unit.

In the McNaughton Formation, the change from coarse feldspathic sediments to mature, marine quartz sandstones, which we assume is approximately correlative with the end of final rifting and the transition to post-rift subsidence, occurs in the lower part or below the early Cambrian Fallotaspis trilobite zone $^{19}$ (Fig. $4 a$ ). The transition to post-rift subsidence, therefore, lies near the base of the Atabanian Stage or in the Tommotian Stage. These stages are not well dated but are thought to range from slightly younger than $570 \mathrm{Myr}$ to $\sim 590 \mathrm{Myr}$ (ref. 20). If the correlation of the McNaughton Formation with the basal conglomeratic unit and the Hamill Group suggested in Fig. $4 a$ is even approximately correct, there is excellent agreement between the stratigraphical position of the rift to post-rift transition and the age of that transition inferred from the subsidence data.

There is also evidence, from work in progress, for syn-depositional rifting in the western United States, in uppermost Proterozoic and lower Cambrian rocks that are broadly correlative with the succession in the southern Canadian Rocky Mountains (Figs 1, 4b). The principal evidence for rifting is the occurrence of feldspathic sandstones and conglomerates, relatively abrupt lateral facies and thickness changes, regionally variable palaeocurrent directions and the presence of mafic volcanic flows and volcaniclastic conglomerates. Few chemical data are available for the volcanic rocks, but the rocks appear to be of tholeiitic to alkalic affinities, consistent with continental rifting ${ }^{1,21}$. The feldspathic sandstones and conglomerates occur sporadically, but in places constitute units several hundred metres thick ${ }^{22,23}$. Sequential changes in mineralogical maturity and grain size are locally abrupt, consistent with episodic uplift and exposure of crystalline basement. In Utah, for example, medium- to fine-grained, well-sorted, shallow-marine (?) quartzite of the upper Browns Hole Formation is overlain with sharp contact by arkosic, poorly sorted fluvial (?) conglomerate of the Geertsen Canyon Quartzite ${ }^{23}$ (Fig. $4 b$ ). In general, the occurrence of lateral facies and thickness changes tends to be obscured by formational nomenclature which emphasizes the regional persistence of gross stratigraphical units. However, in one welldocumented example, the middle member of the Wood Canyon
Formation in southeastern California ${ }^{22}$, strata thicken and coarsen to the north-east and contain south-west-directed palaeocurrents, whereas associated stratigraphical units thicken to the west or north-west, and yield west- to north-directed and polymodal palaeocurrents ${ }^{24,25}$.

The inferred rift deposits in Utah and Nevada overlie strata that are thought to be correlative with the Windermere Supergroup in the Canadian Cordillera ${ }^{26,27}$, and they pass upward into lower Cambrian mature quartz sandstones with Skolithos that lie at the base of the post-rift strata from which the subsidence data were collected (Figs 1, 2, 4b). In the Delamar area of eastern Nevada, lithostratigraphical correlation with a section in the White-Inyo Mountains, California, suggests that the transition upward into post-rift mature quartz sandstones occurs near the base of or below the Fallotaspis trilobite zone ${ }^{26,28}$. In the Wah $\mathrm{Wah}^{29}$ and East Tintic ${ }^{30}$ sections, the transition to post-rift strata is not well dated but seems to occur at about the same stratigraphical level relative to the base of the middle Cambrian as in the Delamar area ${ }^{26}$. In the Huntsville section ${ }^{23,27}$, the transition may be slightly lower stratigraphically but is probably broadly correlative with that to the south. In the western United States, therefore, as in the southern Canadian Rockies, the stratigraphical position of the final rifting to postrift transition is in good agreement with the age of that transition inferred from the subsidence data.

The age of the final rifting episode can also be estimated from stratigraphical relations at several localities in the miogeocline. Near Jasper, in the southern Canadian Rockies, the uppermost $500 \mathrm{~m}$ of the underlying Windermere Supergroup (Miette Group, Fig. 4a) contains the trace fossils Platysolenites and Didmaualichnus and a microbiota with Campitius and Volborthella spp. ${ }^{13,31}$. These are reported to occur in the Tommotion Stage ( $\sim 570-590 \mathrm{Myr})$ and possibly younger stages of the early Cambrian ${ }^{13,32}$, but their range is not well established. The rift deposit clearly lies above the Windermere Supergroup and only a short distance beneath probable earliest Cambrian strata, suggesting a latest Proterozoic age for the deposit. Simlarly, in Utah and Nevada, the mafic volcanic rocks and feldspathic deposits occur a short distance below the Fallotaspis zone in 

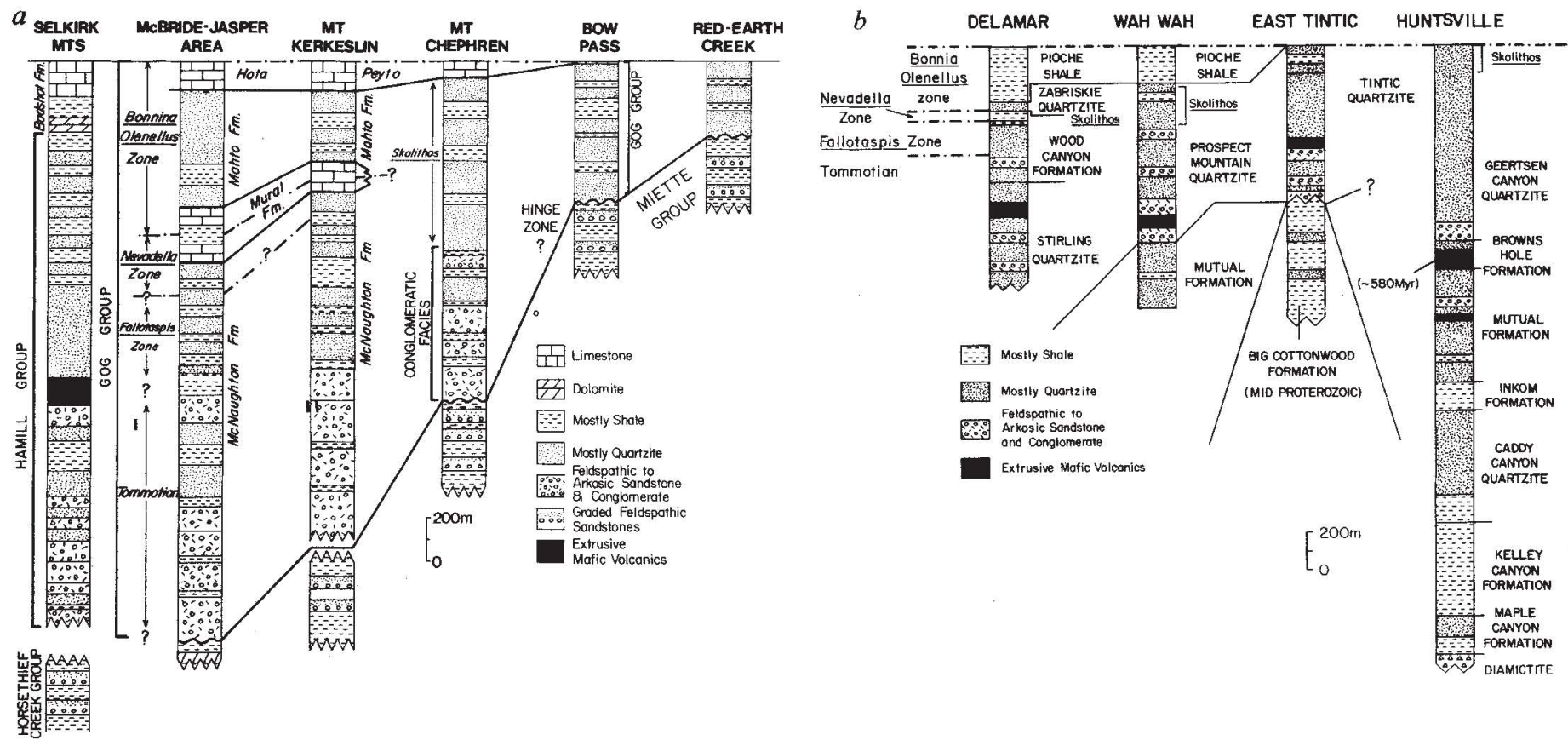

Fig. $4 a$, Respresentative sections of the basal conglomeratic unit of the Gog Group and its probable equivalents in the McNaughton Formation and the Hamill Group. Columns show the transition of these strata to post-rift deposits of the miogeocline. These strata are interpreted as evidence of post-Windermere rifting and latest Proterozoic to earliest Cambrian transition to the post-rift phase in the margin. The Horsethief Creek Group and the Miette Group compose the Windermere Supergroup west and east of the Rocky Mountain Trench, respectively. Dash-dot lines are approximate boundaries between trilobite zones. The base of the middle Cambrian (uppermost dash-dot line) is the reference datum of the sections. The sections are located in Fig. 3 as follows: 1, Red Earth Creek; 5, Bow Pass; 7, Mt Chephren; 12, Mt Kerkeslin; 14, McBride-Jasper area; 17, 18, Selkirk Mts. Sources: Red Earth Creek, Bow Pass and Mt Chephren from G.C.B., Ma and M.A.K. (field work 1982 and 1983); Mt Kerkeslin from refs 13, 43; Selkirk Mts from ref. 16. Faunal zones are from ref. 19. $b$, Representative sections from Utah and Nevada indicating inferred final rift deposits and the transition to post-rift strata for comparison with similar successions in the southern Canadian Rockies. Dash-dot lines are approximate boundaries between trilobite zones. The ages in the Delamar section are based on lithostratigraphical correlation with biostratigraphically dated strata in the White-Inyo Mountains of California, about $300 \mathrm{~km}$ to the west. The upper part of the Stirling Quartzite is correlated with strata assigned a Tommotion age in California; the base of the Tommotion stage has not been established in the western United States ${ }^{34}$. Sections located in Fig. 1 and sources as follows: 11, Delamar ${ }^{26} ; 12$, Wah Wah ${ }^{29}$; 7, East Tintic ${ }^{30} ; 6$, Huntsville ${ }^{23,27}$.

strata that are probably Tommotion in age (Fig. $4 b$ ), which, together with the 580-Myr Ar/Ar age from the volcanic rocks in northern Utah ${ }^{21}$, suggests that rifting occurred in the latest Proterozoic and/or earliest Cambrian. Finally, in Mexico, postrift carbonate rocks and quartz sandstones of early Cambrian age pass gradationally downward into nearly $300 \mathrm{~m}$ of strata containing mafic lava and mafic volcaniclastic rocks. These volcanic deposits seem to be correlative with, or slightly older than, the lower part of the Fallotaspis zone ${ }^{33,34}$.

Large parts of the Cordilleran miogeocline from Canada to Mexico, therefore, contain evidence of late Proterozoic rifting events that led to the formation of an extensive proto-Pacific passive margin. These events began perhaps as early as 800 900 Myr but appear to have terminated in a final, distinct and short-lived phase near the Cambrian-Precambrian boundary. The age is compatible with ages for the final rifting and rift to post-rift transition inferred from quantitative subsidence data. The results of the subsidence analyses were fundamental to this research, not only focusing on the problem of the ages for rifting, but also in predicting the stratigraphical position where the final rift deposit and the transition to post-rift strata should occur. This greatly facilitated the search for these deposits in the field. We have now identified these deposits in a large region in the southern Canadian Rockies and in an even larger area between southeastern Idaho and southeastern California (indicated by the dotted lines in Fig. 1). It seems that final rifting along a large portion of the proto-Pacific margin of western North America occurred at about the same time as rifting in the early Palaeozoic miogeocline in Arctic Canada and along an extensive portion of the lapetus margin in the US Appalachians and Newfoundland ${ }^{7}$. The contemporaneity of these events support recent arguments for rifting around nearly all of the perimeter of North America close to the Cambrian-Precambrian boundary ${ }^{7}$.

The research was supported by NSF grants EAR 82-12737 to G.C.B. and H. Brueckner and EAR 83-13230 to G.C.B. and by the Donors of the Petroleum Research Fund, administered by the American Chemical Society (PRF 16042-G2 to N.C.-B.). We thank Ian Dalziel and Pete Nickeson for helpful reviews and Mary Ann Luckmann and Linda Dalziel for drafting. LamontDoherty Geolgical Observatory contribution no. 3830.

Received 5 November 1984; accepted 11 April 1985.

1. Stewart, J. H. Geology 4, 11-15 (1976).

2. Gabrielse, H. Am. J. Sci. 272, 521-536 (1972).

3. Monger, J. W. H. \& Price, R. A. Can. J. Earth Sci, 16, 770-791 (1979).

4. Bond, G. C. \& Kominz, M. A. Bull, geol. Soc. Am, 95, 155-173 (1984)

5. Bond G. C. Kominz, M. A. \& Devlin, W. J. Nature 306, 775-779 (1983).

6. Armin, R. A. \& Mayer, L. Geology 11, 702-705 (1983).

7. Bond, G. C., Nickeson, P. A.,\& Kominz, M. A. Earth planet. Sci Lett. 70, 325-346 (1984).

8. Miller, F. K., McKee, E. H. \& Yates, R. G. Bull. geol. Soc. Am. 84, 3723-3730 (1973).

9. Cochran, J. R. Earth planet. Sci. Lett, 66, 289-302 (1983).

10. McMechan, M. E. thesis. Queen's Univ., Kingston, Canada (1980)

11. Armstrong, R. L., Eisbacher, G. H. \& Evans, P. D. Can. J. Earth Sci. 19, 316-323 (1982).

12. Devlin, W. J. \& Bond, G. C. Geol. Ass. Can. Prog. Abstr. 8, Al7 (1984).

13. Young, F. G. Geol. Suru. Can. Bull. 288 (1976).

14. Poulton, T. P. \& Simony, P. S. Can. J. Earth Sci. 17, 1708-1724 (1980).

15. Simony, P. S. \& Wind, G. Geol. Ass. Can. spec. Pap. 6, 41-51 (1970).

16. Wheeler, J. O. Geol. Surv. Can. Pap. 6-32 (1963)

17. Bond, G. C. Geol. Ass. Can. Prog. Abstr. 8, A8 (1983).

18. Mountjoy, E. W. \& Aitken, J. D. Bull. Can. Petrol. Geol. 11, 161-168 (1983).

19. Fritz, W. H. \& Mountjoy, E. W. Can. J. Earth Sci. 12, 119-131 (1975)

20. Harland, W. B. et al. A Geologic Time Scale (Cambridge University Press, 1983).

21. Crittenden, M. D. Jr \& Wallace, C. A. in Belt Symp. Vol. 1, 116-138 (University of Idaho and Idaho Bureau of Mines Geology, 1973).

22. Diehl, P. Calif. Div. Mines Geol. Spec. Rep. 106, 51-62 (1976).

23. Crittenden, M. D. Jr U.S. geol. Surv. Map GQ-968 (1972).

24. Stewart, J. H. U.S. geol. Surv. prof. Pap. 620 (1970).

25. Wertz, W. E. in Geol. Soc. Am. 78th A. Meet. Guidebk, Anaheim, California (eds Cooper, J. D., Troxel, B. W. \& Wright, L. A.) 165-170 (1982).

26. Stewart, J. H. J. Res. U.S. geol. Surv. 2, 609-618 (1974). Am. 82, 581-602 (1971). 
28: Mount, J. F., Gevirtzman, D. A. \& Signor, P. W. III Geology 11, 224-226 (1983).

29. Abbott, J. T., Best, M. G. \& Morris, H. T. U.S. geol. Surv. Misc. Inv. Ser. Map 1-1479 (1983).

30. Morris, H. T. \& Lovering, T. S. U.S. geol. Surv, prof. Pap. 36! (1961)

31. Young, F. G. C. J. Earth Sci. 9, 1-17 (1972)

32. Vidal, G. Granl Geol Unders. Bull 134 (1979)

3. McMenamin, M. A. S., Awramik, S. M. \& Stewart, J. H. Geology 11, 227-230 (1983)

34. Stewart, J. H., McMenamin, M. A. S. \& Morales-Ramirez, J. M. U. S. geol. Surv, prof. Pap. 1309 (1984),

35. Hoy, T. B.C. Minist. Energy Mines Petrol. Res. Bull. 73 (1980).

36. McKenzie, D. Earth planet. Sci. Lett. 40, 25-32 (1978).

37. Palmer, A. R. in Cambrian of the New World (ed. Holland, C. H.) 1-78 (Wiley, New York, 1971)

38. Aitken, J. D. Geol. Surv. Can. Bull. (in the press)

39. Price, R. A. \& Fermor, P. R. Geol. Surv. Can. Open File Rep. 882 (1981).

40. Campbell, R. B., Mountjoy, E. W. \& Struick, L. C. Geol Surv. Can. Open File Rep. 844 (1982).

41. Price, R. A. Geol. Soc. Lond. spec. Publ. 9, 1-22 (1980).

42. Price, R. A. \& Mountjoy, E. W. Geol. Ass. Can. spec. Pap. 6, 7-25 (1970)

43. Mountioy, E W Geal Surv Can Pap 61-31 (1962).

\section{Direct measurements of secondary} currents in a meandering sand-bed river

\author{
C. R. Thorne*, L. W. Zevenbergen*, J. C. Pitlick $\dagger$, \\ S. Rais $\dagger$, J. B. Bradley† \& P. Y. Julien $\dagger$ \\ * Department of Geography and Earth Science, Queen Mary College, \\ University of London, Mile End Road, London E1 4NS, UK \\ † Colorado State University, Fort Collins, Colorado 80523, USA
}

Natural channels often adopt a meandering course. Water flow in meander bends is three-dimensional, consisting of primary velocities which are tangential to the bend, and secondary velocities, which are in the radial plane. The pattern of secondary flow strongly affects the distribution of primary velocities. This in turn affects the distribution of erosion and deposition in the bend and the way in which the channel shifts and changes shape. Measurements of primary and secondary flows in a meandering gravel-bed river ${ }^{1,2}$ show that, in addition to the widely recognized main secondary circulation driving surface water outwards and bed water inwards, there can be a small cell of reverse rotation at the outer bank. Further data have been collected in a sand-bedded river at low, intermediate and high discharges. The results confirm the existence of the main and outer bank cells but also indicate that in some bends the main cell does not extend to the inner bank. In fact, secondary flow at the inner bank of wide, shallow bends is directed radially outwards over the whole flow depth at all in-channel flows. This indicates that some models of bend flow and channel development may be significantly in error.

Secondary currents are defined as currents that occur in a plane normal to the axis of primary flow ${ }^{3}$. In meander bends, they develop by skewing of cross-stream vorticity into a longstream direction ${ }^{3,4}$. The resulting skew-induced secondary circulation carries fast surface water towards the outer bank and slower bed water towards the inner bank.

At the outer bank, the primary flow, secondary circulation, and bank interact to produce a small cell of reverse rotation to the skew-induced cell. This cell occupies the channel to a distance one or two times the bank height away from the bank. Although this is a small proportion of the cross-section in most rivers, the outer bank cell is still important because it strongly affects the distribution of boundary shear stress, thereby influencing bank erosion processes ${ }^{5,6}$.

In the central part of the channel, helical skew-induced flow produces inward velocities near the bed, which sweep bedload towards the inner bank. Sediment accumulation as a point bar at the inner bank gives the channel an asymmetrical crosssection. The balance between the transverse, upslope component of fluid drag on a bedload particle, and the transverse, downslope component of particle weight has been used as the basis for models of bed topography in bends ${ }^{7,8}$. This view of secondary flow-point bar interaction has been challenged recently?. Dietrich and Smith suggest that secondary flow above the point bar is directed radially outwards over the whole flow depth and that the helical skew-induced cell is confined to the deepest, or thalweg, portion of the cross-section. Sediment accumulation is
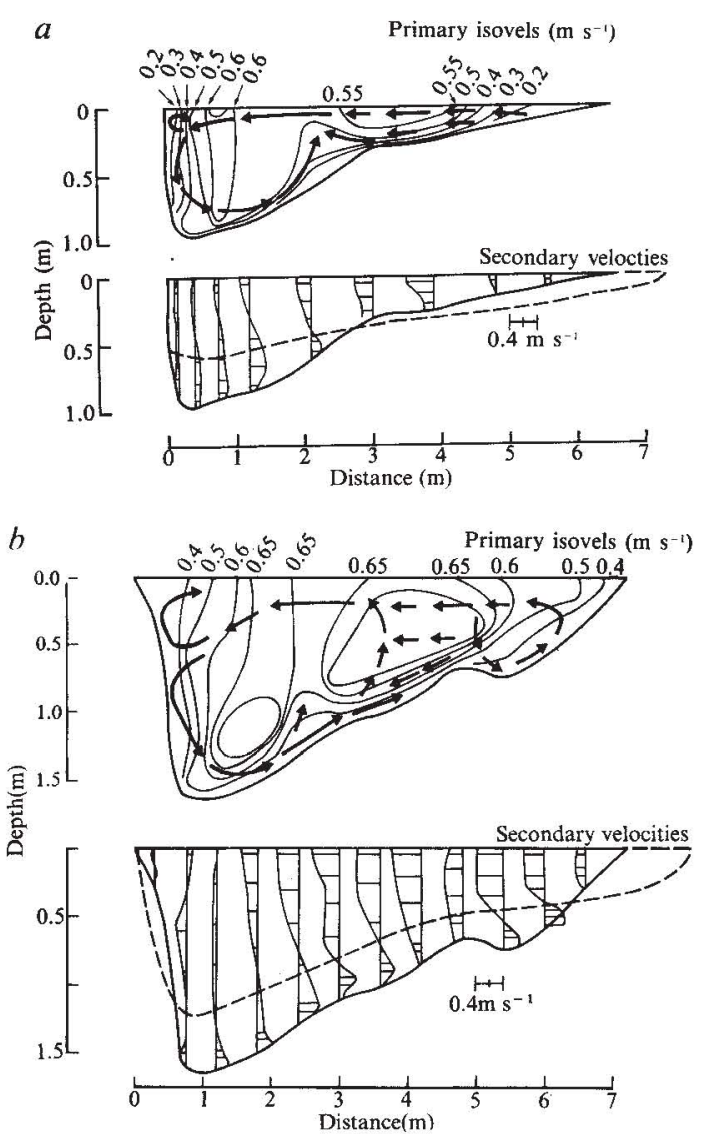

Fig. 1 Upstream bend apex, discharge: $a, 1.7 \mathrm{~m}^{3} \mathrm{~s}^{-1} ; b, 4.0 \mathrm{~m}^{3} \mathrm{~s}^{-1}$. Dashed channel section represents that at the previous measurement section, $\sim 6 \mathrm{~m}$ upstream.

then concentrated on a steep transverse slope called the point bar face, between the upper point bar (point bar platform) and the thalweg, where near bed flow converges and there is strong upwelling. Bridge ${ }^{10}$ suggests that this pattern of flow and point bar building is a characteristic of point bar emergence at flows below about two-thirds bankfull. He suggests that at such low stages the point bar topography causes flow convergence at the bend entrance, but that such patterns are replaced by helical flow at formative (that is, bankfull) discharge.

To help to resolve this discussion, data were collected in this study over a range of discharges in meander bends of the Fall River in Rocky Mountain National Park, Colorado. The reach studied has a bankfull capacity of about $4 \mathrm{~m}^{3} \mathrm{~s}^{-1}$ and well developed meanders with a sinuosity of 2.2 . The annual hydrograph is dominated by snowmelt runoff, resulting in long periods of almost steady bankfull flow in May, June and July. The gradient is $\sim 0.1 \%$. The bed material is sand, $D_{50}=1.0 \mathrm{~mm}$, moving in dunes, ripples and as suspended load. Sediment availability has been greatly increased by erosion associated with the failure of Lawn Lake Dam on the Roaring River (an upstream tributary) on 15 July 1982 . As a result, the bed is mobile at all discharges and point bars in the bends respond quickly to changes in flow stage.

Measurements were made at low, intermediate and bankfull stages, corresponding to discharges of $1.7,2.8$, and $4.0 \mathrm{~m}^{3} \mathrm{~s}^{-1}$. Long and cross-stream velocities were measured using an electromagnetic current meter capable of measuring two mutually perpendicular velocity components with an accuracy of $\pm 3 \mathrm{~mm} \mathrm{~s}^{-1}$. All measurements were made from temporary bridges aligned at right angles to the outer bank, and care was taken to work only over dune crests, avoiding separation zones on the lee side of dunes. Data were collected at 18 sections evenly spaced along the channel through two consecutive bends. The complete data set is available $\mathrm{e}^{11,12}$ but because of limitations of space, only data for the intermediate and high flow at the 